traditional in type. In Southern Germany, for example, gold vessels were still being made not only at the end of the Bronze Age but also during the first Iron Age period (which followed); similar vessels produced after 1000 B.C. and decorated especially with simple bridle bits, have been recovered in other areas such as Spain.

In general, however, the great flourishing in the art and practice of making precious metal jewellery and ornaments, which spread throughout most of Europe in the Bronze Age, had died away by the end of the 8 th century. During the Iron Age which followed, gold apparently was much less available and it became more an exclusive attribute of 'princes' and their funerary wealth. It played a much smaller role in the lives of communities and ordinary people than appears to have been the case previously. In any event, the production of heavy and massive ornaments and jewellery (Figure 14) then came to an end and the emphasis thenceforth was to be on the techniques of using gold in the form of leaf and foil, and upon the artistic exploitation of these for decorative purposes.

\section{Gold Alloy Compositions}

The compositions of the golds used in ancient jewellery production can be determined spectrographically and the results provide a means of studying various aspects of ancient gold technology, including principally those related to the methods of acquisition of the primary metal. Some examples are given here which illustrate the types of conclusions that can be drawn from data on the proportions of silver, copper and tin determined in this way on gold samples from individual pieces.

Figure 15(a) shows a schematic representation of the silver, copper and tin contents of 'lunules'. Those from the different regions are not distinguished by characteristic compositions. In this respect it must be borne in mind, that the bulk of the gold used may have been derived from gold nuggets sufficiently large to be substantially free from a mixture with tin. Some gold used, however, and especially that with high tin content, may have been made from fine gold grains collected from rivers containing grains of the tin ore, cassiterite. Since the latter has a high specific gravity, grains of it would almost certainly have been collected together with the gold grains.

Figure 15(b) represents schematically the composition of gold vessels from Germany and northern Europe. The golds of the small vessels (A) appear fairly uniform in composition and differ from the golds of the tall conical vessels (B), such as that shown in Figure 8, of the Middle Bronze Age.

In Figure 15(c) are shown the compositions of the golds of the long bar-torcs of Britain and Ireland. Those of Irish specimens are distinguished from those of British specimens by their higher content of tin. These are from the Middle Bronze Age or the beginning of the Late Bronze Age $(1,2)$.

The compositions of the gold of 'hair-rings' the Late Bronze
Age from Ireland are shown schematically in Figure 15(d). They all show a high copper content. These copper-containing alloys which were in general use around 800 B.C. began to appear during the Middle Bronze Age $(1,2)$.

\section{References}

1 A. Hartmann, 'Prähistorische Goldfunde aus Europa' , Part 1, 1970 and Part 2, 1982, Studien für den Aufängen der Metallurgie, Berlin

2 J.J. Taylor, 'Bronze Age Goldwork of the British Isles', Cambridge University Press, 1980

3 C. Eluère, 'Les Ors Préhistoriques - l' Agc des Bronze en France 2', Picard, Paris, 1982

4 G. Eogan, 'Lock Rings of the Latc Bronze Age', Proc. Roy. Irish Acad., 1969, 67, 129-195

5 M. Almagro-Gorbea, 'Orfebreria del Bronze Final in la Peninsula Iberica...' 'Trabajos de Prehistorica', Chap. XXXI, pp. 39-90, 1974

6 C. Eluère, 'Les Premiers Ors de France', Bull. Soc. Préhist. Francaise, 1977, 74, 390-419

7 See (2), p. 27

8 See (2), p. 11

9 W. Menghin and P. Schaucr 'Magisches Gold', Germanisches Nationalmuseum, Nuremberg, 1977, pp. 45-50

10 C. Eluère, Archéologia, 1982, 173, Dec., 19-25

\title{
French Goldwork in Antiquity
}

Les Ors Préhistoriques by Christinane eluêre, Picard, Paris, 1982, 287 pages, FF250

The more than 400 gold artifacts found in France and which have been dated as belonging to the period extending from the end of the $3 \mathrm{rd}$ millenium to the 8 th century B.C. are listed and indexed in this recent book by the author of the preceding article.

Eluère's book is abundantly illustrated with phorographs, macrophotographs and drawings. It therefore constitutes an important and valuable reference work in which is embodied all the information currently available on each prehistoric gold artifact from France. However, this compilation is more a beginning than an end. The closing chapters of the book, in which the author discusses the possible role of gold and various types of goldwork among the peoples of the Bronze Age, are revealing of our lack of knowledge in this area. Eluère's detailed contribution provides those interested in studying the role of gold in prehistoric times more deeply with a comprehensive and well documented record of all the objects which have been recovered in France to date. 